Article

\title{
GHG Mitigation Potential of Different Grazing Strategies in the United States Southern Great Plains
}

\author{
Tong Wang ${ }^{1, *}$, W. Richard Teague ${ }^{2}$, Seong C. Park ${ }^{2}$ and Stan Bevers ${ }^{3}$ \\ 1 Department of Economics, South Dakota State University, Brookings, SD 57007, USA \\ 2 Texas A\&M AgriLife Research, Vernon, TX 76384, USA; \\ E-Mails: rteague@ag.tamu.edu (W.R.T.); scpark@ag.tamu.edu (S.C.P.) \\ 3 Texas A\&M AgriLife Extension, Vernon, TX 76384, USA; E-Mail: s-bevers@tamu.edu \\ * Author to whom correspondence should be addressed; E-Mail: tong.wang@sdstate.edu; \\ Tel.: +1-605-688-4863; Fax: +1-605-688-6386.
}

Academic Editor: Marc A. Rosen

Received: 21 July 2015 / Accepted: 25 September 2015/ Published: 30 September 2015

\begin{abstract}
The possibility of reducing greenhouse gas (GHG) emissions by ruminants using improved grazing is investigated by estimating GHG emissions for cow-calf farms under light continuous (LC), heavy continuous (HC) and rotational grazing, also known as multi-paddock (MP), management strategies in Southern Great Plain (SGP) using life cycle assessment (LCA). Our results indicated a GHG emission with these grazing treatments of $8034.90 \mathrm{~kg} \cdot \mathrm{CO}_{2} \mathrm{e} \cdot \mathrm{calf}^{-1} \cdot$ year $^{-1}$ for cow-calf farms in SGP region, which is high, compared to that for other regions, due to the high percentage (79.6\%) of enteric $\mathrm{CH}_{4}$ emissions caused by relatively lower feed quality on the unfertilized rangeland. Sensitivity analyses on MP grazing strategy showed that an increase in grass quality and digestibility could potentially reduce GHG emission by 30\%. Despite higher GHG emissions on a per calf basis, net GHG emissions in SGP region are potentially negative when carbon $(\mathrm{C})$ sequestration is taken into account. With net $\mathrm{C}$ emission rates of $-2002.8,-1731.6$ and $-89.5 \mathrm{~kg} \mathrm{C}^{-1} \cdot \mathrm{year}^{-1}$ after converting from $\mathrm{HC}$ to $\mathrm{MP}, \mathrm{HC}$ to $\mathrm{LC}$ and from LC to MP, our analysis indicated cow-calf farms converting from continuous to MP grazing in SGP region are likely net carbon sinks for decades.
\end{abstract}

Keywords: rotational grazing; greenhouse gas; life cycle assessment; $\mathrm{C}$ sequestration; Southern Great Plains 


\section{Introduction}

Ruminants, particularly beef cattle, are perceived by many as a problem since they are a source of greenhouse gas (GHG) due to the methane produced by rumen fermentation [1]. However, it is premature to decide on appropriate management actions or policies until full ecosystem analyses have outlined net emissions by considering all emissions compared to carbon sequestration associated with different options in the beef production chain [2]. Since the major portion of the beef production chain involves animals grazing on perennial pastures, an important initial step would be to gather GHG emissions and carbon (C) sequestration data to determine net emissions using life cycle assessment (LCA) for different grazing strategies on perennial pastures.

For beef cattle production, management practices in different regions vary greatly in terms of stocking rate, mean cow size, calving season, primary forage types and fertilizer use [3]. Therefore, an ideal LCA model is one that is regionally specific. Our LCA modeling is applicable to the cow-calf only production phase in the Southern Great Plains (SGP) region of USA, where one third of US cow-calf only farms are located [4], and no known net-emission LCA study regarding cow-calf production on perennial pastures has been conducted.

Traditional ranching in the South Central U.S. has generally been based on continuous yearlong grazing practices. Rotational grazing, also known as multi-paddock grazing (MP), has been recommended since the mid-20th century as an important tool to adaptively manage grazing land ecosystems for the purpose of sustaining productivity and improving animal management. Under rotational grazing management, one paddock is grazed at a time while the other paddocks recover. There is published and anecdotal evidence from producers that, if applied appropriately to produce most advantageous results, rotational grazing can lead to improved forage and livestock production [5-8]. Simulation modeling also indicates that there tend to be larger profit margins and restoration of ecological condition with rotational grazing compared to traditional grazing $[9,10]$. However, few studies have been conducted to compare GHG emissions and C sequestration relations among different grazing strategies.

In this study we calculate the carbon footprints for cow-calf farmers under continuous and rotational grazing strategies using life cycle assessment (LCA) modeling, which is a standard assessment of the environmental impacts associated with a wide range of agricultural systems using a "cradle-to-grave" approach. Compared to the sector approach which only includes emissions from direct farm activities, LCA also includes indirect emissions generated by farm inputs and pre-chain activities.

Previous LCA studies on beef production have consistently reported that the cow-calf phase contributes the most emissions to the overall beef production system [11]. However, they generally omitted carbon sequestration, which has great potential to mitigate GHG emissions for cow-calf production as $\mathrm{C}$ sequestration exceeds emissions when animals feed solely by grazing perennial pastures $[5,12]$. In addition, net emissions are rarely analyzed on the same farm to estimate the GHG balance [13] and changes in C stock resulting from different grazing management practices are generally not known [14]. As grazing management practices have impacts on both GHG emissions and carbon sequestration, it is important to consider $\mathrm{C}$ sequestration in conjunction with $\mathrm{GHG}$ emissions on the same ranch to provide an objective evaluation of the GHG mitigation potential of advanced grazing management strategies. 
In our study we considered both GHG emissions and C sequestration to calculate net GHG emissions for cow-calf farms under different grazing strategies. Based on Teague et al. [15], three grazing management alternatives on neighboring commercial ranches in three proximate counties in north Texas tall grass prairie are considered, including: (1) continuous grazing with light stocking (LC), representing the best-case scenario for continuous grazing; (2) traditional heavily stocked continuous grazing (HC), representing the most commonly used grazing management; and (3) adaptively managed and stocked rotational grazing, or multi-paddock grazing (MP), representing the best case scenario for rotational grazing $[6,8,10]$. GHG emissions were evaluated for the cow-calf farms under the three different grazing strategies using LCA approach. In addition, soil organic carbon (SOC) stock under the same grazing strategies were calculated using the soil carbon parameters measured by Teague et al. [15]. Based on both GHG emission and SOC stock values, we developed net $\mathrm{C}$ emission budgets for different farm transition scenarios, namely transiting from HC to MP, from HC to LC and from LC to MP.

\section{Methods and Materials}

\subsection{The Study System}

The goal of our study is to assess the GHG emissions and carbon sequestration from different grazing management options for representative cow-calf enterprises in the Southern Great Plain (SGP) region. A detailed description of these three management practices can be found in Teague et al. [15]. The life

cycle we consider includes the entire production period from the start of the breeding season in April, to the point when the weaned calves are sold, in November of the following year as depicted in Figure 1. Cattle transportation from the site of cow-calf production to the next phase of production is not considered. The functional unit, to which all the environmental loads in the LCA are related, is generally defined as $1 \mathrm{~kg}$ live or carcass weight if the entire beef production systems are studied, which includes cow-calf, backgrounding and finishing systems [11]. As the boundary of our LCA study is limited to the calf-cow production system, we define the functional unit as one marketed beef calf as in Ogino et al. [16], so that our result can be easily compared with literature value from other regions. In addition, to capture the stocking density differences of different grazing strategies, we have also used one hectare of rangeland as the alternative functional unit.

Beef producers and regional extension experts have described the current cow calf production conditions in SGP area as follows. Most ranchers in the SGP area follow a breeding season from April to August, resulting in calf births from January to May. Weaning occurs from September to November. The production cycle of the year-1 cohort overlaps with the production cycle of the year- 2 cohort. Specifically, during the breeding period and part of the gestation period, the cows still feed the previous cohort of calves. Similarly, during the lactation period of the current cohort, the cows will breed and become pregnant with the next cohort. Based on the contemporary production data, Figure 1a-c describe the timeline of the calf production cycle for the mature cows, 1st-year heifers and 2nd-year heifers respectively. Note that in Figure 1b, the female cattle start as 1st-year heifers, but turn into 2nd-year heifers at their second breeding season and eventually become mature cows at the end of our defined production cycle. Similarly, in Figure 1c, the female cattle start as 2nd-year heifers, then become mature cows after weaning their firstborn calves. For all female cattle for reproduction purpose, for simplicity 
we assume the same average pregnancy rate, lactation rate and weaning rate as $90 \%, 86 \%$ and $82 \%$, respectively.

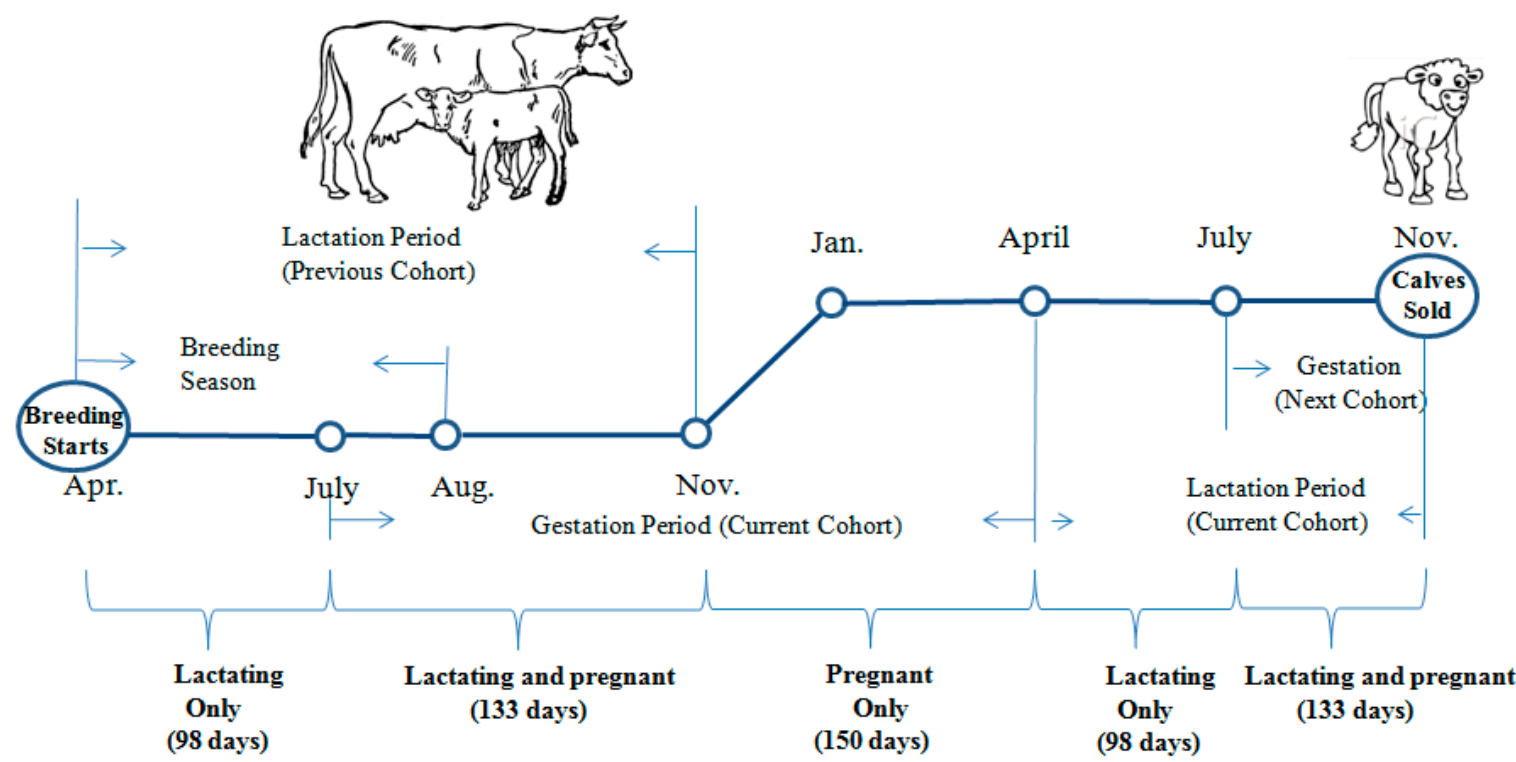

(a)

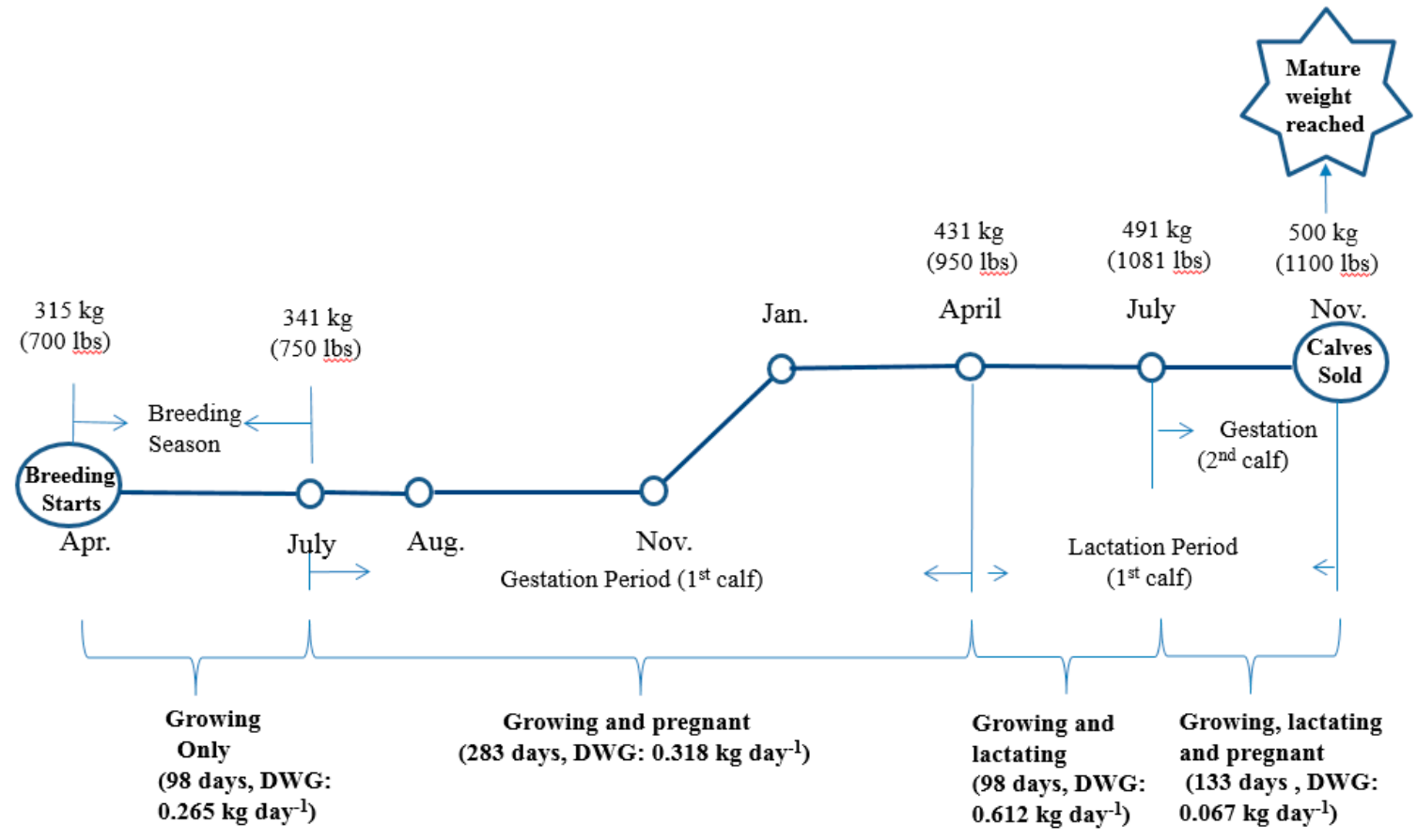

(b)

Figure 1. Cont. 


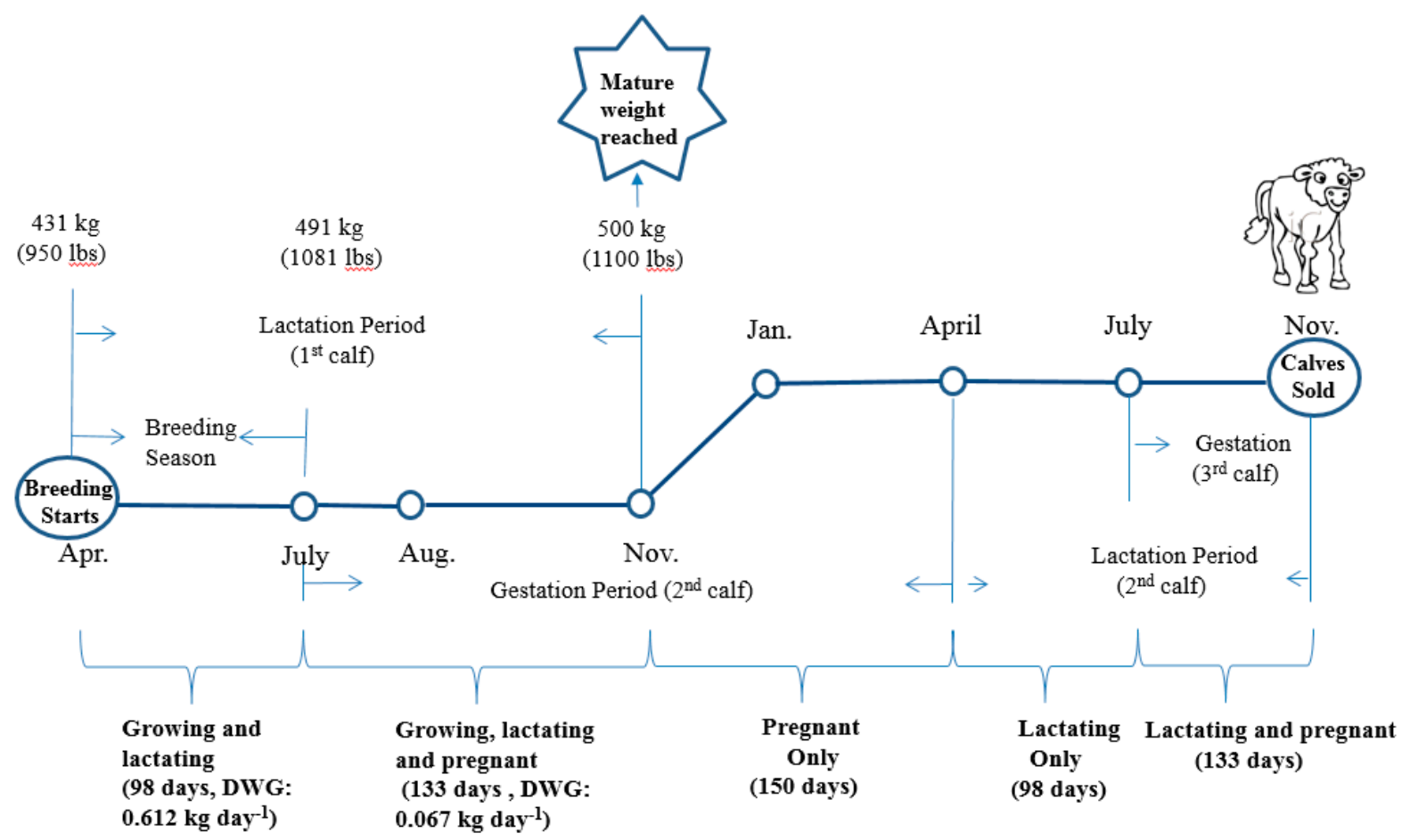

(c)

Figure 1. (a) Timeline of a production period for female cattle starting as mature cows; (b) Timeline of a production period for female cattle starting as 1st-year heifers; (c) Timeline of a production period for female cattle starting as 2nd-year heifers.

For demonstration purpose a uniform gestation period for all cows from July to the following April is assumed. Take Figure 1a, the production timeline for mature cows for example, based on a 283-day pregnancy this gives 133 days of overlap between pregnancy and lactation and 150 days of pregnancy without lactation. Prior to each gestation period, we assume a 98-day period of lactating only for the previous cohort. On average, pregnancy rate, lactation rate and weaning rate are $90 \%, 86 \%$ and $82 \%$, respectively. Thus, in this production cycle described in Figure 1a, 82\% of the cows spend 196 days lactating but not pregnant, 150 days pregnant but not lactating, and 266 days both lactating and pregnant, totaling 612 days. Among the rest, $14 \%$ of cows didn't calve, based on the $86 \%$ lactating rate. It was assumed that all cows that didn't calve were neither lactating nor pregnant during the entire 612-day period. About $4 \%$ of cows give birth but do not raise a calf to the weaning stage. We assume these cows did not lactate during the entire 612-day period. Based on Figure 1 we assume these $4 \%$ of cows are pregnant for a period of 416 days in the production cycle and are neither lactating nor pregnant for the remaining 196 days.

Of the 332 weaned calves, except for the 53 that are retained as replacement heifers, the rest of the calves are sold immediately after weaning in November. The replacement heifers get bred for the first time during the next year's breeding season, and will be pregnancy checked at around 19 months old. They typically reach their mature weight when they wean their firstborn calves. After that they will stop growing and will remain on the ranch until ten to eleven years old. Figure 1b, c resemble Figure 1a in the breeding season, gestation period and lactation period. However, as 1st-year heifers are growing through the production season, and 2nd-year heifers also grow part of the production season, activities 
that attributes to enteric methane emission are different for 1st, 2nd-year heifers and mature cows even at the same production stage, as marked in Figure 1a-c.

In SGP region, the cattle are grazed on native prairie pasture $100 \%$ of the time. Supplemental hay is rarely used in the SGP region, except for the years of severe drought, therefore we will not take it into account in our study. In this region cotton seed meal is commonly used as a protein supplement during the winter when grass protein is low and we calculate the GHG emissions associated with this source of feed. The cows, 1 st and 2nd-year heifers and bulls are fed 0.908 kilograms ( 2 pounds) of supplemental protein per head per day for 120 days.

Descriptions of the breakdown of cattle numbers for LC, HC and MP grazing can be found in Table 1.The total area of the representative farm in SGP area is defined as 4000 hectare. Given that 1 Animal Unit (AU) equals $450 \mathrm{~kg}$, the stocking rates for LC grazing herd in SGP area is $14 \mathrm{AUs} 100 \mathrm{ha}^{-1}$, while those for HC and MP are both $27 \mathrm{AUs} 100 \mathrm{ha}^{-1}$, as described in Teague et al. [15]. In SGP region,

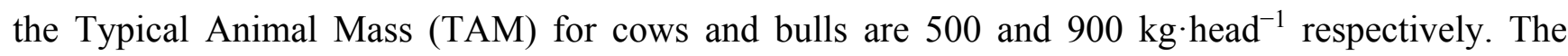
1st-year heifers weight $408 \mathrm{~kg}$ on average during the production cycle, as they start to breed in April at 12 months of age weighting $315 \mathrm{~kg}$, and reach the mature cow weight of $500 \mathrm{~kg}$ by the time they wean their firstborn calves (Figure 1b). The 2 nd-year heifers start at $431 \mathrm{~kg}$ at beginning of the $2 \mathrm{nd}$ breeding season and their weights stabilize at $500 \mathrm{~kg}$ after weaning their firstborn calves (Figure 1c). Therefore the weighted average weight for 2nd-year heifer is $487 \mathrm{~kg}$ during the production cycle. The TAM for calves is $40 \mathrm{~kg}$ at birth and $220 \mathrm{~kg}$ at weaning age, so we used the average value of $130 \mathrm{~kg}$ per head. Based on expert's opinion, the herd under LC grazing is comprised of 299 mature cows, 53 1st-year heifers, 53 2nd-year heifers, and 13 bulls. Based on the $82 \%$ weaning rate, 332 calves are weaned under LC grazing strategy. The proportion of cows, heifers, bulls and calves under HC and MP grazing are the same as the LC system.

Table 1. A description of the representative farms under three different grazing strategies.

\begin{tabular}{cccc}
\hline Parameters & $\begin{array}{c}\text { Light } \\
\text { Continuous (LC) }\end{array}$ & $\begin{array}{c}\text { Heavy } \\
\text { Continuous (HC) }\end{array}$ & Multi-Paddock (MP) \\
\hline Total number of cattle & 750 & 1446 & 1446 \\
\hline cows & 299 & 576 & 576 \\
\hline 1st year heifers & 53 & 102 & 102 \\
\hline 2nd year heifers & 53 & 102 & 102 \\
\hline calves & 332 & 640 & 640 \\
\hline bulls & 13 & 26 & 26 \\
\hline Typical Animal Mass (TAM) & & & $500 \mathrm{~kg}$ \\
\hline cows & $500 \mathrm{~kg}[1.11 \mathrm{AU}]$ & $500 \mathrm{~kg}$ & $408 \mathrm{~kg}$ \\
\hline 1st year heifers & $408 \mathrm{~kg}[0.91 \mathrm{AU}]$ & $408 \mathrm{~kg}$ & $487 \mathrm{~kg}$ \\
\hline 2nd year heifers & $487 \mathrm{~kg}[1.08 \mathrm{AU}]$ & $487 \mathrm{~kg}$ & $900 \mathrm{~kg}$ \\
\hline calves & $130 \mathrm{~kg}[0.29 \mathrm{AU}]$ & $130 \mathrm{~kg}$ & 1080 \\
\hline bulls & $900 \mathrm{~kg}[2.00 \mathrm{AU}]$ & $900 \mathrm{~kg}$ & $4000 \mathrm{ha}$ \\
\hline Total AUs & 560 & 1080 & 27 \\
\hline Total hectare & $4000 \mathrm{ha}$ & $4000 \mathrm{ha}$ & $90 \%$ \\
\hline Stocking rate $\left(\mathrm{AU} 100 \mathrm{ha}^{-1}\right)$ & 14 & 27 & \\
\hline Pregnancy rate & $90 \%$ & $90 \%$ &
\end{tabular}


Table 1. Cont.

\begin{tabular}{|c|c|c|c|}
\hline Parameters & $\begin{array}{c}\text { Light } \\
\text { Continuous (LC) }\end{array}$ & $\begin{array}{c}\text { Heavy } \\
\text { Continuous (HC) }\end{array}$ & Multi-Paddock (MP) \\
\hline Calving rate & $86 \%$ & $86 \%$ & $86 \%$ \\
\hline Weaning rate & $82 \%$ & $82 \%$ & $82 \%$ \\
\hline Breeding Season & April to August & April to August & April to August \\
\hline Birth & Next January to May & Next January to May & Next January to May \\
\hline Weaning & $\begin{array}{c}\text { Next September } \\
\text { to November }\end{array}$ & $\begin{array}{c}\text { Next September to } \\
\text { November }\end{array}$ & $\begin{array}{c}\text { Next September to } \\
\text { November }\end{array}$ \\
\hline Weaning age & 7 months & 7 months & 7 months \\
\hline Supplemental hay & $\begin{array}{c}\text { Rarely used, except for } \\
\text { severe drought years }\end{array}$ & $\begin{array}{c}\text { Rarely used, except for } \\
\text { severe drought years }\end{array}$ & $\begin{array}{c}\text { Rarely used, except for } \\
\text { severe drought years }\end{array}$ \\
\hline $\begin{array}{l}\text { Supplemental protein } \\
\text { (cotton seed meal) }\end{array}$ & $\begin{array}{c}2 \text { pounds cow }{ }^{-1} \cdot \text { day }^{-1} \\
\text { for } 120 \text { days }\end{array}$ & $\begin{array}{c}2 \text { pounds } \operatorname{cow}^{-1} \cdot \text { day }^{-1} \\
\text { for } 120 \text { days }\end{array}$ & $\begin{array}{c}2 \text { pounds cow } \\
\text { for } 120 \text { days }\end{array}$ \\
\hline \multicolumn{4}{|l|}{ Energy use } \\
\hline diesel & 6.07 gallons/ha & 6.07 gallons/ha & 6.07 gallons/ha \\
\hline gasoline & 0.74 gallons/ha & 0.74 gallons $/$ ha & 0.74 gallons/ha \\
\hline LP gas & 1.62 gallons/ha & 1.62 gallons/ha & 1.62 gallons/ha \\
\hline electric & $59.24 \mathrm{kWh} / \mathrm{ha}$ & $59.24 \mathrm{kWh} / \mathrm{ha}$ & $59.24 \mathrm{kWh} / \mathrm{ha}$ \\
\hline \multicolumn{4}{|l|}{ Fertilizer use } \\
\hline $\mathrm{N}$ & 0 & 0 & 0 \\
\hline $\mathrm{P}$ & 0 & 0 & 0 \\
\hline
\end{tabular}

Pregnancy rates as well as the lactating and weaning rates across three different grazing strategies are assumed the same as the average corresponding rates described previously in this section. This assumption is based on previous literature findings, which reported no differences in pregnancy rate for cows associated with different stocking-rate treatments [17-20], cows maintained on continuous grazing and variable rotational grazing treatments [21,22], and cows under continuous and rotational stocking at identical stocking rates [23,24].

\subsection{GHG Emissions}

In this section we describe the methodologies used in GHG emission calculations. The environmental loads associated with beef cow-calf production are animal body, supplemental feed production and animal management. Specifically, five components of GHG emission on a typical SGP cow-calf farm were included: enteric methane emission, manure methane emission, manure nitrous oxide $\left(\mathrm{N}_{2} \mathrm{O}\right)$ emission, supplemental protein $\mathrm{CO}_{2}$ emission and $\mathrm{GHG}$ emission from farm energy use and fertilizer use. For the first three components, GHG emissions were first calculated using IPCC [25] on a per production cycle basis, then converted to the annual basis to be compatible in time frame with GHG emissions the last two components and carbon sequestration.

In addition, all gases were converted to $\mathrm{CO}_{2}$ equivalents $(\mathrm{CO} 2 \mathrm{e})$ to account for the global warming potential, where $\mathrm{CO}_{2}=1, \mathrm{CH}_{4}=25$ and $\mathrm{N}_{2} \mathrm{O}=298$ [26]. To compare GHG emission with carbon sequestration, $\mathrm{CO}_{2} \mathrm{e}$ is also converted to carbon equivalents $(\mathrm{CE})$, where $\mathrm{CO}_{2} e=12 / 44 \cdot \mathrm{CE}$, according to Environmental Protection Agency [EPA] [27]. 


\subsubsection{Enteric $\mathrm{CH}_{4}$}

Based on IPCC [25], $\mathrm{CH}_{4 \text { enteric }}=\sum_{i} E F_{i} \cdot N_{i}$ (Unit: $\mathrm{kg} \mathrm{CH} 4$ per production cycle), where $N_{i}$ is the number of animals in subcategory $i$ and $E F_{i}$ is the emission factor for the animals in subcategory $i$ with the unit of measurement being $\mathrm{kg} \cdot \mathrm{CH}_{4} \cdot$ head $^{-1} \cdot$ year $^{-1}$. Here $i=1$ denotes cows that are both lactating and pregnant; $i=2$ denotes cows that are lactating but not pregnant; $i=3$ denotes cows that pregnant but not lactating; $i=4$ denotes cows that are neither pregnant nor lactating; $i=5$ denotes 1 st-year heifers that are growing only; $i=6$ denotes 1 st-year heifers that are growing and pregnant; $i=7$ denotes 2nd-year heifers that are growing and lactating; $i=8$ denotes 2nd-year heifers that are growing, pregnant and lactating; $i=9$ denotes bulls and $i=10$ denotes calves.

According to IPCC [25], "the Tier 2 method should be used if enteric fermentation is a key source category for the animal category that represents a large portion of the country's total emissions." Clearly, Tier 2 approach should be adopted for beef cattle. Using Tier 2 approach $E F_{i}$ is calculated as:

$$
E F_{i}=G E_{i} \cdot Y_{m} \cdot D a y_{i} / 55.65
$$

where $Y_{m}$ is the methane conversion factor, which is the percent of gross energy in feed converted to methane. Based on IPCC [25], $Y_{m}=6.5 \pm 1.0$. Lower bound is more appropriate for feed with high digestibility and high energy value, and vice versa. Without better information, the mean value is chosen for our baseline analysis. For calves fed entirely on milk, IPCC [25] specified that $Y_{m}=0$. However, as their rumens develop, the calves also starts to emit methane, IPCC [25] did not provide any information on $Y_{m}$ for this category. Unaware of any enteric methane emission data for calves in SGP region, we will use the methane emission rate measured by Westberg et al. [28] for four calves on pasture owned by Washington State University Department of Animal Sciences. At the time of measurement, these four suckling calves were at 4 months in age weighing $206 \mathrm{~kg}$ on average, and were temporarily separated from their mothers. Since the average calf weight is $130 \mathrm{~kg}$ in our production cycle, we will proportionally adjust the measurement of Westberg et al. (2001), which was $2.2 \mathrm{~g} \cdot \mathrm{day}^{-1} \cdot \mathrm{calf}^{-1}$, by $T A M^{0.75}$ [25]. The average daily enteric emission for calves is thus calculated as $2.2 / 206^{0.75} \cdot 130^{0.75}=1.6 \mathrm{~g} \cdot$ day $^{-1} \cdot$ calf $^{-1}$ in our case.

Factor $55.65\left(\mathrm{MJ} / \mathrm{kg} \mathrm{CH}_{4}\right)$ stands for the energy content of methane. Day $y_{i}$ denotes the number of days that the animals actually stayed on the farm; $G E_{i}$ is the gross energy intake (Unit: MJ $\cdot$ head $^{-1} \cdot \mathrm{day}^{-1}$ ), which is further defined as:

$$
G E_{i}=\left[\left(N E_{i}^{m}+N E_{i}^{a}+N E_{i}^{l}+N E_{i}^{p}\right) / R E M+N E_{i}^{g} / R E G\right] / D E
$$

here $N E_{i}^{m}$ is the net energy for maintenance, required by the animal so that body energy is neither gained or lost, which is calculated by $N E_{i}^{m}=C f_{i} \cdot T A M_{i}^{0.75}$. Here, coefficient $C f_{i}$ takes the value of 0.386 for lactating female cattle $(i=1,2,7,8), 0.322$ for non-lactating females $(i=3,4,5,6)$ and 0.370 for bulls $(i=9)$.

Next, $N E_{i}^{a}=C_{a} \cdot N E_{i}^{m}$ stands for the net energy for activity, or the energy needed by the animal to obtain food, water and shelter. It is based on the feeding situation rather than the feed itself. For cattle confined in a small area such as a barn, $C_{a}=0$; for cattle confined in areas with sufficient forage such 
as a pasture $C_{a}=0.17$; for cattle grazing in an open rangeland, $C_{a}=0.36$. In our study the cattle graze an open rangeland, thus, $C_{a}=0.36$ is chosen.

For lactating cows $(i=1,2,7,8), N E_{i}^{l}=\operatorname{Milk} \cdot(1.47+0.40 \cdot f a t)$ is the net energy for lactation, where Milk is the amount of milk produced $\left(\mathrm{kg} \cdot \mathrm{day}^{-1}\right)$ and $f a t$ is the fat content of milk (\%). According to EPA [29], the monthly lactation estimates for beef cows from January to December are respectively, 1.5, 2.3, 3.9, 5.4, 6.2, 6.0, 5.3, 4.2, 3.1, 2.0, 1.4 and $1.3 \mathrm{~kg} \cdot$ beef $\cdot \mathrm{cow}^{-1} \cdot \mathrm{day}^{-1}$. According to Figure 1, if the calves are born in early April and weaned late November, the average daily milk production would be $4.21 \mathrm{~kg} \cdot \mathrm{day}^{-1}$. Also according to EPA [29], there is 4 per cent of fat in milk. For pregnant cows $(i=1,3,6,8), N E_{i}^{p}$ is the net energy required for pregnancy, where $N E_{i}^{p}=0.1 \cdot N E_{i}^{m}$.

For heifers, $N E_{i}^{g} \quad(i=5,6,7,8)$ is the net energy for growth, defined as $N E_{i}^{g}=22.02 \cdot[B W /(C \cdot M W)]^{0.75} \cdot W G^{1.097}$, where $B W$ is the TAM of the heifer $(\mathrm{kg}) ; C$ is a coefficient with a value of 0.8 for heifers; $M W$ is the mature live body weight of an adult female in moderate body condition $(\mathrm{kg})$, or TAM of the cow; $W G$ is the average daily weight gain of the heifers, as demonstrated in Figures $1 \mathrm{~b}$ and $1 \mathrm{c}$ for heifers at different life stages.

Feed digestibility ( $D E$ ) for cattle ranges from $45 \%$ to $55 \%$ for crop byproducts and range lands and $55 \%$ to $75 \%$ for good pastures, good preserved forages and gain supplemented forage based diets. In Southern Great Plains, we use the intermediate digestibility value for rangeland, that is $D E=50$. Finally, we calculate $R E M$ and $R E G$ based on $D E \% . R E M$ is the ratio of net energy available in diet for maintenance to digestible energy consumed:

$$
R E M=1.123-4.092 \cdot 10^{-3} \cdot D E+1.126 \cdot 10^{-5} \cdot D E^{2}-25.4 / D E
$$

$R E G$ is the ratio of net energy available in diet for growth to digestible energy consumed:

$$
R E G=1.164-5.160 \cdot 10^{-3} \cdot D E+1.308 \cdot 10^{-5} \cdot D E^{2}-37.4 / D E
$$

\subsubsection{Manure $\mathrm{CH}_{4}$}

On a cow-calf farm, cattle directly deposit dung and urine on the native prairie pasture where they graze all year long. Storage and treatment of manure, which occur very often when large animals are managed in a confined area, such as the feedlot, is not applicable to the cow-calf production in SGP region. Based on IPCC [25], compared to manure stored or treated as a liquid, manure deposited on pastures and rangelands tend to produce less manure $\mathrm{CH}_{4}$.

To calculate manure methane emission, the method provided by ICF Consulting (ICF) [30] is used, which is very similar to the Tier 2 method in IPCC [25], but is more informative in that instead of treating the North American region as a whole, it treats each state in U.S. separately. Overall, the manure methane emission can be calculated as:

$$
C H_{4 \text { manure }}=\sum_{i} \sum_{j} V S_{i} \cdot B_{0} \cdot M C F_{j} \cdot W S_{i j}
$$

where $V S_{i}$ stands for the volatile solid produced by all the animals in subcategory $i$ per year and it can be computed from:

$$
V S_{i}=N_{i} \cdot T A M_{i} \cdot V S_{\text {coeffi }}
$$


According to ICF [30], VS coefficient $\left(V S_{\text {coeffi }}\right)$ is 2.6 (unit: $\mathrm{kg} \mathrm{VS} / \mathrm{kg}$ animal mass/year). Thus, $T A M_{i} \cdot V S_{\text {coeffi }}$ values for calves, heifers, cows and bulls can be calculated as 338, 819, 1300 and 2340 (kg/animal/year). Note that EPA [29] also provides $T A M_{i} \cdot V S_{\text {coeffi }}$ as a single value $V S$ (kg/animal/year) for the year 2010. As per EPA [29], for two available categories, heifers and cows, VS took the value of 1013 and 1589 respectively in Oklahoma, and 1053 and 1664 respectively in Texas. These estimates are about 25\% higher than the estimates using the ICF [30] method. Therefore our estimates are adjusted by a factor of 1.25 to obtain the updated estimates for all four categories. The adjusted $T A M_{i} \cdot V S_{\text {coeffi }}$ values for calves, 1st-year heifers, 2nd-year heifers, cows and bulls are 423, 1326, 1583, 1625 and 2925 (kg/animal/year) respectively.

$B_{0}$ is the estimate of maximum methane producing capacity of U.S. livestock. For beef NOT in feedlots, $B_{0}=2.72 \cdot 0.0413$ (Unit: $\mathrm{kg}$ per $\mathrm{kg}$ VS). Note that to maintain the consistency of unit we have changed the value of $B_{0}$ accordingly, which, according to ICF [30], took the value of 2.72 (Unit: $\mathrm{ft}^{3}$ per $\mathrm{lb} \mathrm{VS})$. Also note that $1 \mathrm{ft}^{3}=0.0413 \mathrm{lbs}$ [30]. $W S_{i j}$ is the percent of animal $i$ 's manure managed in manure system $j$. For all animal categories we assume a 100\% pasture/range/paddock manure system, for which the methane conversion factor (MCF) for manure system is $1.4 \%$ in both Texas and Oklahoma.

\subsubsection{Manure $\mathrm{N}_{2} \mathrm{O}$}

According to IPCC [25], the $\mathrm{N}_{2} \mathrm{O}$ emissions generated by manure in the system "pasture, range and paddock" occur directly and indirectly from the soil. Besides urine and dung, no other forms of manure such as organic $\mathrm{N}$ addition and synthetic fertilizer are applied on the native pasture. Therefore, direct $\mathrm{N}_{2} \mathrm{O}$ emissions from urine and dung inputs to grazed soils can be calculated as (Unit: $\mathrm{kg}$ $\mathrm{N}_{2} \mathrm{O}$ /production period):

$$
N_{2} O_{\text {direct }}=F_{\text {direct }} \cdot E F_{3} \cdot 44 / 28
$$

where $F_{\text {direct }}$ (Unit: $\mathrm{kg} \mathrm{N}$ /production period ) is the amount of non-volatilized nitrogen excreted by grazing animals on pasture, range and paddock in a production period. The value of $F_{\text {direct }}$ can be estimated by ICF [31] method, that is:

$$
F_{\text {direct }}=\sum_{i} 0.8 \cdot N_{i} \cdot\left(\text { TAM }_{i} / 1000\right) \cdot K_{N} \cdot D a y_{i}
$$

Kjeldahl Nitrogen per day per $1000 \mathrm{~kg}$ mass, or $K_{N}$ (Unit: $\mathrm{kg} \mathrm{N} /$ day), takes the value of 0.34 . Figure 1 shows that calves stay on the pasture for a total of 462 days (231 days for each cohort) during the production period, while the other subcategories of animals are assumed to stay on the farm throughout the production period. $E F_{3}$ (Unit: $\mathrm{kg} \mathrm{N} 2 \mathrm{O} / \mathrm{kg} \mathrm{N}$ ) is the emission factor for $\mathrm{N}_{2} \mathrm{O}$ emissions from urine and dung deposited by grazing animals on pasture, range and paddock. According to IPCC [25], $\mathrm{EF}_{3}$ takes a default value of 0.02 with uncertainty range between 0.007 and 0.06 . Without better information, we will choose the default value of $E F_{3}$ for all three grazing strategies.

In addition to direct emissions of $\mathrm{N}_{2} \mathrm{O}$, emissions of $\mathrm{N}_{2} \mathrm{O}$ also take place in two indirect channels, (1) through the volatilization of nitrogen as $\mathrm{NH}_{3}$ and oxides of nitrogen and deposition of these gases and their products back onto soils, and (2) through leaching and runoff of nitrogen. Based on IPCC [25], 
leaching and runoff are unlikely to occur for dryland regions, where precipitation is lower than evapotranspiration most time of the year. Therefore we assume that under the semi-arid climate of SGP region, leaching and runoff do not occur on cow-calf farms, as they are typically non-irrigated and unfertilized. Thus, indirect $\mathrm{N}_{2} \mathrm{O}$ emissions can be calculated as:

$$
\mathrm{N}_{2} \mathrm{O}_{\text {indirect }}=F_{\text {indirect }} \cdot E F_{4} \cdot 44 / 28
$$

where $F_{\text {indirect }}$ is the amount of nitrogen deposited by grazing animals on pasture, range and paddock (Unit: $\mathrm{kg} \mathrm{N} /$ production period), which can be calculated as:

$$
F_{\text {indirect }}=\sum_{i} \phi \cdot N_{i} \cdot\left(\text { TAM }_{i} / 1000\right) \cdot K_{N} \cdot \text { Day }_{i}
$$

where $\phi$ is the fraction of volatilized nitrogen as $\mathrm{NH}_{3}$ and $\mathrm{NOx}$, which takes a default value of 0.2 with uncertainty range between 0.05 and 0.5 [27]. $E F_{4}$ is the emission factor for $\mathrm{N}_{2} \mathrm{O}$ emissions atmospheric deposition of nitrogen on soils, which takes a default value of 0.01 with uncertainty range between 0.002 and 0.05 [27]. Without further information, we will assume default values for both $\phi$ and $E F_{4}$.

\subsubsection{Protein Supplement}

In the SGP region cottonseed meal is used as the main source of supplemental protein. The majority of cotton seed available as supplement for beef cattle in Texas and Oklahoma is from central pivot irrigation (pers. comm. with Dr. Paul DeLaune, Environmental Soil Scientist, Texas A\&M AgriLife Research, Vernon, Texas.). According to van Zeist et al. [32], the yield of cotton is divided into fibers $(38 \%)$ and seed $(62 \%)$, of which $5 \%$ of seed is reserved for replanting. The yields of this cotton seed from central pivot irrigation for industrial production purpose is $3030 \mathrm{~kg} \cdot \mathrm{ha}^{-1}$ and field production $\mathrm{GHG}$ emissions is $884 \mathrm{CE} \cdot \mathrm{ha}^{-1}$ [33]. We assume that $57 \%$ of the $\mathrm{GHG}$ emission is attributable to the cottonseed for non-reproduction purpose and calculated the emissions at $503.88 \mathrm{~kg} \cdot \mathrm{CE} \cdot \mathrm{ha}^{-1}$. Thus, the field level GHG emission for cottonseed production is estimated as $0.17 \mathrm{~kg} \mathrm{CE}$ per $\mathrm{kg}$ of cottonseed in the field.

Energy required for crushing cottonseed is $1.25 \mathrm{~mm} \mathrm{BTU}$ per ton of cottonseed crushed, when natural gas is used as the main source of thermal energy [34]. According to EPA [27], the carbon content coefficient is $14.47 \mathrm{~kg} \cdot \mathrm{C} \cdot \mathrm{per} \cdot \mathrm{mm}$ Btu for natural gas; therefore, the GHG emission is $18.09 \mathrm{~kg}$ CE per ton of cottonseed crushed, or $0.02 \mathrm{~kg} \mathrm{CE}$ per kg of cottonseed crushed. Together, GHG emission is 0.19 $\mathrm{kg}$ CE per $\mathrm{kg}$ of cottonseed. For $1000 \mathrm{~kg}$ of cottonseed yield, industry-wide yields are $160 \mathrm{~kg}$ cottonseed oil, $455 \mathrm{~kg}$ cottonseed meal, $270 \mathrm{~kg}$ husks, $83.5 \mathrm{~kg}$ linters and $31.5 \mathrm{~kg}$ being lost. If we assume that $45.5 \%$ of GHG emission on cottonseed is attributable to cotton seed meal, then GHG emission is $0.19 \mathrm{~kg}$ CE per $\mathrm{kg}$ of cottonseed meal produced.

According to U.S. Department of Agriculture (USDA)-National Agricultural Statistics Service (NASS) Crop Production report released in August 12, 2015, the 2014 harvested area for upland cotton production in Texas was 1,861,519 hectare $(4,600,000$ acres). In addition, based on the statistics provided by National Cattlemen's Beef Association [35], for the year 2014 there were 4350,000 cows that calved in Texas. Given that each cow is fed $0.908 \mathrm{~kg}$ of supplemental protein per head per day in winter for 120 days, and that the yields of this cotton seed from central pivot irrigation as $3030 \mathrm{~kg} \cdot \mathrm{ha}^{-1}$ as we assumed above, together the calved cows consume $8.4 \%$ of the annual cotton harvested if they were planted under central pivot irrigation. Therefore the land currently used for cotton 
production is sufficient to meet the cow-calf farm's protein supplementation requirement. As no land use conversion to cotton production is necessary, GHG emission associated with land use change effect will not be considered in this paper.

\subsubsection{Energy Use $\mathrm{CO}_{2}$}

Ryan and Tiffany [36] reported fuel related energy expenses of $\$ 10.24$ per head for cow-calf operators in 1995, with the energy use breakdown data as 6.07, 0.74, 1.62 gallons for diesel, gasoline and LP gas respectively, and 59.24 kWh for electric. Based on 124,884 Btu per gallon and $3413 \mathrm{Btu}$ per $\mathrm{kWh}$, the energy use were 758,046, 92,414, 202,312 and 202,186 Btu for diesel, gasoline, LP gas and electric respectively. According to the conversion unit provided in Del Grosso, Walsh and Duffield [37], the GHG emission from diesel, gasoline, LP gas and electric are 54.89, 6.48, $12.62,34.87 \mathrm{~kg} \mathrm{CO}_{2}$ equivalents respectively on a per cow basis.

\subsubsection{GHG Emissions-Sensitivity Analysis}

GHG emission calculation methods for the baseline scenario were provided in the previous sections. For continuous grazing strategies (LC and HC) only the baseline scenarios were considered. To gain a better insight into rotational grazing, both the baseline scenario and several alternative scenarios were considered. Compared to continuous grazing strategies, rotational grazing improved grass composition [15] and forage quality [38]. Therefore two factors related to forage quality are allowed to alter: the methane conversion factor $Y_{m}$ in Equation (1) and the feed digestibility factor ( $D E$ ) in Equations (3) and (4). In addition, under rotational grazing strategy the animals are confined for a short period to a grazing paddock that is much smaller compared to that in continuous grazing. Thus, the lower value of $C_{a}$ is also chosen, which is the coefficient to calculate $N E_{i}^{a}$, the energy needed to obtain food, water and shelter.

Overall, for rotational grazing we considered four scenarios: (i) the baseline scenario; (ii) lower methane conversion factor and higher feed digestibility ( $Y_{m}=5.5$ and $\left.D E=60\right)$, lower energy in obtaining food by choosing the average value of $C_{a}$ between pasture grazing and open rangeland grazing ( $\left.C_{a}=0.265\right)$; (iii) lower methane conversion factor and higher feed digestibility $\left(Y_{m}=5.5\right.$ and $\left.D E=60\right)$, energy to obtain food the same as baseline $\left(C_{a}=0.36\right)$; and (iv) methane conversion factor and feed digestibility the same as baseline $\left(Y_{m}=6.5\right.$ and $\left.D E=50\right)$, and lower energy to obtain food $\left(C_{a}=0.265\right)$.

\subsection{Carbon Sequestration of Rangeland}

\subsubsection{Soil Organic Carbon (SOC) Stock}

With the soil organic matter (\%) available in Teague et al. [15], we calculated the soil organic matter as:

$$
S O M=\sum_{k} \text { density }_{k} \cdot \text { volume } S \mathrm{SO}_{k} \%
$$

Here $k=1$ refers to soil of depth $0-15 \mathrm{~cm} ; k=2$ refers to soil of depth $15-30 \mathrm{~cm}$ and $k=3$ refers to

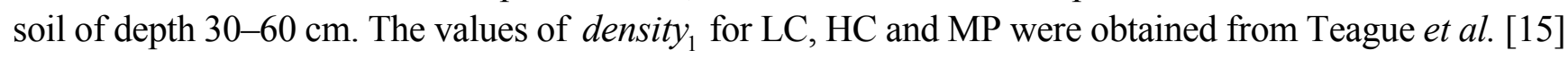


as $0.98,1.06$ and $0.91 \mathrm{Mg} \cdot \mathrm{m}^{-3}$. Bulk density at other soil depth levels was not measured in Teague et al. [15]. Therefore the values of density $_{2} /$ density $_{1}$ and density $/$ density $_{1}$ were first obtained from the average soil density values of the 6-year, 26-year and 60-year old restored grassland as measured by Potter, Torbert, Johnson, and Tischler [39]. Assuming the bulk density in soil depth of $0-15 \mathrm{~cm}$ (average bulk density among bulk density of soil depth of $0-5 \mathrm{~cm}, 5-10 \mathrm{~cm}$ and $10-15 \mathrm{~cm}$ ) as $100 \%$, then the bulk density in the soil depth of $15-30 \mathrm{~cm}$ (weighted average bulk density of $15-20 \mathrm{~cm}$ and $20-30 \mathrm{~cm}$ ) and $30-60 \mathrm{~cm}$ (weighted average of $30-40 \mathrm{~cm}$ and $40-60 \mathrm{~cm}$ ) are $115.1 \%$ and $120.8 \%$ respectively, taking the average of the three grassland sites. Percentages of soil organic matter (SOM) at various soil depths are denoted as $S O M_{k} \%$, which can be obtained from Teague et al. [15] for LC, HC and MP grazing strategies. The corresponding SOC can be computed given that SOM contains 58\% carbon [40].

\subsubsection{Carbon Sequestration}

Teague et al. [15] studied three ranches practicing LC, HC and MP strategies in each of three adjacent counties. The same grazing strategy has been practiced for at least 9 years before the measurements were taken. Of the three ranches currently practicing MP grazing, two were converted from HC to MP, and one was originally under LC. The conversion occurred 10 years previously for the first two ranches and 20 years previously for the third ranch before the year of measurement. One of the limitations of this study is that the carbon stock measurement from previous years is unavailable. The farms with LC, HC and MP practices for each county, however, are located right across the fences from one another or nearby. Therefore, it is reasonable to assume that the MP practicing farms initially had the same SOC stock as the neighboring $\mathrm{HC}$ or LC farms if the conversion had not occurred. Similar to Stephenson et al. [41], we first establish the carbon stock for LC and HC as the benchmark, and consider the relative changes in carbon stock when the conversion to different grazing practices occurred.

We considered three transitions: HC to MP, HC to LC and LC to MP. For sensitivity analysis purposes, three timing scenarios are also considered, namely transition occurring 10, 15 and 20 years prior to transition. To calculate carbon sequestration for each scenario, we adopted the methods used in Gascoigne et al. [42] and divided the difference in carbon stock by the number of years passed since conversion occurred. For example, if during the past $T(T=10,15,20)$ years the total carbon stock of up to $60 \mathrm{~cm}$ soil depth has increased from $C S_{1}$ to $C S_{2} \mathrm{Mg} \cdot \mathrm{ha}^{-1}$ due to the change in management practice, then this implies an annual sequestration rate of $\left(C S_{2}-C S_{1}\right) / T \mathrm{Mg} \cdot \mathrm{ha}^{-1}$ per year. It is worth noting that when applying this method to the data in Potter et al. [39], it generated $412 \mathrm{~kg} \cdot \mathrm{ha}^{-1}$ sequestration rate per year, very close to their regression result of $447 \mathrm{~kg} \cdot \mathrm{ha}^{-1}$ sequestration rate. When there is no management improvement, for example, if $\mathrm{HC}$ or LC is always in practice without conversion to MP, then we assume the soil reaches an equilibrium and the $\mathrm{C}$ sequestration is zero [43]. 


\section{Results and Discussion}

\subsection{GHG Emissions}

Table 2 demonstrated GHG emissions for LC, HC and MP grazing strategies. Note that for the MP baseline scenario, we assumed the same parameters as continuous grazing in LCA approach. Such assumption is later on relieved in MP alternative scenarios to account for the potential improvement in grass quality and the less required energy as animals are confined in a much smaller paddock under MP scenario.

On a per calf basis, the total emission is $8034.90 \mathrm{~kg} \cdot \mathrm{CO}_{2 \mathrm{e}} \cdot \mathrm{calf}^{-1} \cdot \mathrm{year}^{-1}$ for $\mathrm{LC}, \mathrm{HC}$ and MP baseline scenario, due to the same pregnancy and weaning rates assumed for the three grazing strategies based on previous literature observations. Though no difference in pregnancy rates were found under different stocking rate and management strategy, Arthington, Bohlen and Roka [18] showed pounds of calf weaned per acre of dedicated land was greater for high compared to medium and low stocking rates. Therefore the three grazing systems will differ in carbon emissions per pounds of calf weaned. Due to lack of field measured data in SGP area and no comparable literature values, pounds of calf weaned will not be used as the functional unit in our paper. To make a comparison with the carbon sequestration, total carbon emission is also computed on a per hectare basis, for which the value for LC is proportionally lower than those for $\mathrm{HC}$ and MP, due to the different stocking rates.

Table 2. Greenhouse gas (GHG) emissions for farms of different management systems.

\begin{tabular}{ccccccc}
\hline $\begin{array}{c}\text { GHG Emission } \\
\left(\mathbf{k g} \cdot \mathbf{C O} \mathbf{C O}_{\mathbf{2}} \cdot \mathbf{c a l f}^{-\mathbf{1}} \cdot \mathbf{y e a r}^{-\mathbf{1}} \mathbf{)}\right.\end{array}$ & $\mathbf{L C}$ & $\mathbf{H C}$ & $\begin{array}{c}\text { MP } \\
\text { Baseline }\end{array}$ & $\begin{array}{c}\text { MP } \\
\text { Alternative 1 }\end{array}$ & $\begin{array}{c}\text { MP } \\
\text { Alternative 2 }\end{array}$ & $\begin{array}{c}\text { MP } \\
\text { Alternative 3 }\end{array}$ \\
\hline Enteric $\mathrm{CH}_{4}$ emission & 6392.45 & 6392.45 & 6392.45 & 3771.23 & 4002.77 & 6022.06 \\
\hline Manure $\mathrm{CH}_{4}$ emission & 155.84 & 155.84 & 155.84 & 155.84 & 155.84 & 155.84 \\
\hline Manure $\mathrm{N}_{2} \mathrm{O}$ emission & 1275.71 & 1275.71 & 1275.71 & 1275.71 & 1275.71 & 1275.71 \\
\hline Protein Supplement & 195.60 & 195.60 & 195.60 & 195.60 & 195.60 & 195.60 \\
\hline Energy Use $\mathrm{CO}_{2}$ & 115.31 & 115.31 & 115.31 & 115.31 & 115.31 & 115.31 \\
\hline Total Emission & 8034.90 & 8034.90 & 8034.90 & 5413.69 & 5645.22 & 7664.52 \\
\hline $\begin{array}{c}\text { Total Emission } \\
\left(\mathrm{kg} \cdot \mathrm{CE} \cdot \mathrm{calf}^{-1} \cdot \mathrm{year}^{-1}\right)\end{array}$ & 2189.76 & 2189.76 & 2189.76 & 1476.46 & 1539.61 & 2090.32 \\
\hline $\begin{array}{c}\text { Total Emission } \\
\left(\mathrm{kg} \cdot \mathrm{CE} \cdot \mathrm{ha}^{-1} \cdot \mathrm{year}^{-1}\right)\end{array}$ & 181.75 & 350.52 & 350.52 & 236.23 & 246.34 & 334.45 \\
\hline
\end{tabular}

For a cow-calf farm in Upper Midwestern U.S. that provides 75 calves for beef production, Pelletier et al. [44] reported a total GHG emission of 599 ton $\mathrm{CO}_{2 \mathrm{e}}$, which is equivalent to $7986.67 \mathrm{~kg} \cdot \mathrm{CO}_{2 \mathrm{e}} \cdot \mathrm{calf}^{-1}$. This overall emission is only $0.6 \%$ lower than the value calculated in this paper. However, on a cow-calf system in Japan, Ogino et al. [16] reported a total GHG emission of $4550 \mathrm{~kg} \cdot \mathrm{CO}_{2 \mathrm{e}} \cdot \mathrm{calf}^{-1}$ which is $43.3 \%$ lower than the GHG emissions found in this study.

Among the sources of GHG emission presented in Table 2, we can calculate the emission distribution as $79.6 \%$ for enteric $\mathrm{CH}_{4}, 1.9 \%$ for manure $\mathrm{CH}_{4}, 15.9 \%$ for manure $\mathrm{N}_{2} \mathrm{O}, 1.2 \%$ for protein supplement and $1.4 \%$ for energy use. Clearly enteric methane accounts for the majority of all emissions, with emission from manure $\left(\mathrm{CH}_{4}\right.$ and $\left.\mathrm{N}_{2} \mathrm{O}\right)$ ranking next. GHG emissions from the two other sources only 
account for less than $3 \%$ of the total emission, which is almost negligible. Enteric methane accounts for $43.4 \%$ of the total GHG production for the cow-calf farm in Upper Midwestern U.S. [44] and 61.2\% of the total emission in Japan [16], both of which are much lower than our estimation.

The vast gaps in percentage of GHG emissions from different subcategories of cow-calf production can be explained largely by the different production practices resulting from regional variation in climate and grazing conditions [4]. For example, the representative farm studied in Pelletier et al. [44] likely used supplemental forage to sustain cows during winter. However, in the SGP region we studied, cows graze year round on native pasture and generally no harvested forage is necessary for the winter months. As a result, feed production, though not needed for SGP region, is the second largest emission category in Pelletier et al. [44], accounting for $32.9 \%$ of the total emission. Similar differences can be found in the cow-calf system in Japan [16], which reported $18.4 \%$ and $8.3 \%$ of the total emission attributable to feed production and feed transport. Feed transport, which is not applicable in our study, is necessary in the study of Ogino et al. [16], due to the $25 \%$ of imported feed from U.S. and China.

The major reason that SGP region has much higher GHG emissions for cow-calf production is due to the much higher enteric $\mathrm{CH}_{4}$ emissions, which is caused by relatively lower feed quality on the unfertilized rangeland compared to that on the fertilized pasture. As our sensitivity analyses on MP grazing show, if we take account of the potential of grass quality improvement by MP grazing [38], as well as the reduced grazing energy due to much smaller paddock sizes of MP, then MP grazing reduces the total GHG emission by $33 \%$ to $5413.69 \mathrm{~kg} \cdot \mathrm{CO}_{2 \mathrm{e}} \cdot$ calf $^{-1}$ year ${ }^{-1}$, as reflected by the MP Alternative 1 scenario in Table 2. Even if the reduced grazing energy potentially caused by MP grazing is not accounted for, the total GHG will still be lowered to $5645.22 \mathrm{~kg} \cdot \mathrm{CO}_{2 \mathrm{e}} \cdot \mathrm{calf}^{-1} \cdot \mathrm{year}^{-1}$ (MP Alternative 2). However, if the benefit for MP grazing in LCA analysis is only limited to reduced grazing energy while the grass quality remains the same, then GHG emission will be lowered by less than $5 \%$ from the baseline scenario (MP Alternative 3).

These results underline the importance of grass quality improvement in reducing methane $\mathrm{CH}_{4}$ emission, and in return the total GHG emission. With the potential to increase grass quality and digestibility [38], MP grazing could lead to a big reduction in GHG emission. Note that our results on methane reduction by MP grazing is consistent with the field study conducted by DeRamus et al. [45], who measured methane emissions of cattle on different grazing management practices using methane collection equipment, and found a $22 \%$ reduction in annual methane emission from MP grazing when compared with continuous grazing.

\subsection{Carbon Sequestration}

Table 3 shows that the SOC stock up to $60 \mathrm{~cm}$ depth for LC, HC and MP management practices are 122.6, 93.9 and $129.2 \mathrm{Mg} \cdot \mathrm{ha}^{-1}$ respectively. Therefore, MP grazing led to the highest SOC stock, with LC slightly lagging behind by only $5 \%$. HC has the lowest SOC stock, which is $27 \%$ lower than that for MP. Note that our results on SOC stock were comparable to the findings of Potter et al. [39], also in SGP region, where the SOC stock for the 6-year, 26-year and 60-year restored grassland, which were original agricultural land, were $110.0,103.1$ and $132.6 \mathrm{Mg} \cdot \mathrm{ha}^{-1}$ respectively. We can see that our SOC stock value for the MP scenario is very close to that of the 60-year restored grassland; even SOC stock for LC is much higher than the 6-year and 26-year restored grassland. However, SOC stock for HC 
scenario fell far behind, which suggests HC grazing generated very little or no carbon sequestration over the time. This observation coincides with that of Follett and Reed [46], which showed improved grazing management, with its introduction of legumes, control of undesirable species and enhanced grass productivity, generally increases carbon sequestration. Meanwhile, moderate continuous grazing leads to a higher margin of $\mathrm{C}$ sequestered over GHG emission than heavy continuous grazing [12].

Table 3. Carbon stock for farms of different management systems.

\begin{tabular}{|c|c|c|c|}
\hline GHG Sequestration & $\mathrm{LC}$ & $\mathrm{HC}$ & MP \\
\hline \multicolumn{4}{|l|}{ Soil bulk density $\left(\mathrm{Mg} \cdot \mathrm{m}^{-3}\right)$} \\
\hline $0-15 \mathrm{~cm}$ & $0.98^{\mathrm{a}}$ & $1.06^{\mathrm{a}}$ & $0.91^{\mathrm{a}}$ \\
\hline $15-30 \mathrm{~cm}$ & 1.13 & 1.22 & 1.05 \\
\hline $30-60 \mathrm{~cm}$ & 1.18 & 1.28 & 1.10 \\
\hline \multicolumn{4}{|l|}{ SOM (\%) } \\
\hline $0-15 \mathrm{~cm}$ & $5.24^{\mathrm{a}}$ & $3.76^{\mathrm{a}}$ & $5.72^{\mathrm{a}}$ \\
\hline $15-30 \mathrm{~cm}$ & $3.55^{\mathrm{a}}$ & $2.45^{\mathrm{a}}$ & $4.00^{\mathrm{a}}$ \\
\hline $30-60 \mathrm{~cm}$ & $2.09^{\mathrm{a}}$ & $1.49^{\mathrm{a}}$ & $2.48^{\mathrm{a}}$ \\
\hline \multicolumn{4}{|l|}{$\mathrm{SOM}\left(\mathrm{Mg} \cdot \mathrm{ha}^{-1}\right)$} \\
\hline $0-15 \mathrm{~cm}$ & 77.0 & 59.8 & 78.1 \\
\hline $15-30 \mathrm{~cm}$ & 60.1 & 44.8 & 62.8 \\
\hline $30-60 \mathrm{~cm}$ & 74.2 & 57.2 & 81.8 \\
\hline $\mathrm{SOM}\left(0\right.$ to $\left.60 \mathrm{~cm}, \mathrm{Mg} \cdot \mathrm{ha}^{-1}\right)$ & 211.3 & 161.9 & 222.7 \\
\hline SOC $\left(0\right.$ to $\left.60 \mathrm{~cm}, \mathrm{Mg} \cdot \mathrm{ha}^{-1}\right)$ & 122.6 & 93.9 & 129.2 \\
\hline
\end{tabular}

a Values from Teague et al. [15].

From Table 4 we can see that carbon sequestration rates varied greatly for different scenarios, with highest $\mathrm{C}$ sequestration rate for the 10 -year transition scenario and the lowest $\mathrm{C}$ sequestration for the 20 -year scenario. This is because if the same accrual of SOC stock occurs under a shorter period of time, then SOC accumulation rate for each year is in return higher, which means higher SOC sequestration. Note that SOC stock may not increase with the same accrual rate each year. As pointed out by Follett and Reed [46], relatively high $\mathrm{C}$ sequestration occurs on recently restored rangelands (up to $2.75 \mathrm{Mg} \cdot \mathrm{C} \cdot \mathrm{ha}^{-1} \cdot$ year $^{-1}$ ) while lower $\mathrm{C}$ sequestration occurs $\left(0\right.$ to $1.6 \mathrm{Mg} \cdot \mathrm{C} \cdot \mathrm{ha}^{-1} \cdot$ year $^{-1}$ ) on rangelands managed the same way over the long term.

Given any transition period, the highest sequestration always occurred during the transition from $\mathrm{HC}$ to MP, while the sequestration rate under transition from HC to LC ranks second, generating slightly lower $\mathrm{C}$ sequestration, and the sequestration rate from LC to MP is much lower, generating only $20 \%$ of the highest $\mathrm{C}$ sequestration rate. Therefore $\mathrm{C}$ sequestration rate is closely tied to the initial land use practice. Transitioning from LC to MP generates a $\mathrm{C}$ sequestration rate of $330 \mathrm{~kg} \cdot \mathrm{C} \cdot \mathrm{ha}^{-1} \cdot \mathrm{year}^{-1}$, which is consistent with most carbon sequestration rates reported by the literature. For example, Stephenson et al. [41] reports a $\mathrm{C}$ sequestration rate of MP grazing lies within the range of 120 to $400 \mathrm{~kg} \cdot \mathrm{C} \cdot \mathrm{ha}^{-1} \cdot \mathrm{year}^{-1}$, and in the NGP region, Liebig et al. [12] report C sequestration rates of 390 to $460 \mathrm{~kg} \cdot \mathrm{C} \cdot \mathrm{ha}^{-1} \cdot \mathrm{year}^{-1}$ for the unfertilized native prairie and fertilized crested wheatgrass. Soussana et al. [47] also obtained annual C sequestration rates between 191 and $491 \mathrm{C} \cdot \mathrm{ha}^{-1} \cdot \mathrm{year}^{-1}$ when modeling the European grassland management systems. After converting from HC to MP, the C 
sequestration rate was estimated as a much higher value of $1765 \mathrm{~kg} \cdot \mathrm{C} \cdot \mathrm{ha}^{-1} \cdot \mathrm{year}^{-1}$, which is consistent with the finding of Soussana et al. [48], who reported a C sequestration rate of $2400 \pm 700 \mathrm{~kg} \cdot \mathrm{C} \cdot \mathrm{ha}^{-1} \cdot \mathrm{year}^{-1}$. This is because when poor management lowered SOC stock over the time, a transition to an improved practice such as MP will increase SOC stock at a higher rate [43].

Table 4. Possible (net) carbon emission and sequestration for different transition scenarios.

\begin{tabular}{cccc}
\hline $\begin{array}{c}\text { C Emission/Sequestration } \\
\left(\mathbf{k g} \cdot \mathbf{C E} \cdot \mathbf{h a}^{\mathbf{- 1}} \cdot \mathbf{y e a r}^{-\mathbf{1}} \mathbf{)}\right.\end{array}$ & 10-Year & 15-Year & 20-Year \\
\hline $\mathrm{C} \mathrm{Sequestration}$ & & & \\
\hline $\mathrm{HC} \rightarrow \mathrm{MP}$ & 3530.0 & 2353.3 & 1765.0 \\
$\mathrm{HC} \rightarrow \mathrm{LC}$ & 2870.0 & 1913.3 & 1435.0 \\
$\mathrm{LC} \rightarrow \mathrm{MP}$ & 660.0 & 440.0 & 330.0 \\
\hline $\mathrm{C} \mathrm{Emission}$ & & & \\
\hline $\mathrm{HC} \rightarrow \mathrm{MP}$ & 350.52 & 350.52 & 350.52 \\
$\mathrm{HC} \rightarrow \mathrm{LC}$ & 181.75 & 181.75 & 181.75 \\
$\mathrm{LC} \rightarrow \mathrm{MP}$ & 350.52 & 350.52 & 350.52 \\
\hline $\mathrm{Net} \mathrm{C} \mathrm{Emission}$ & & & \\
\hline $\mathrm{HC} \rightarrow \mathrm{MP}$ & -3179.5 & -2002.8 & -1414.5 \\
$\mathrm{HC} \rightarrow \mathrm{LC}$ & -2688.3 & -1731.6 & -1253.3 \\
$\mathrm{LC} \rightarrow \mathrm{MP}$ & -309.5 & -89.5 & 20.5 \\
\hline
\end{tabular}

To be conservative on the GHG mitigation potential of MP grazing, GHG emission from only MP baseline scenario in Table 2 is used to estimate carbon balance. Similar to Liebig et al. [12], who observed that unfertilized native prairie was a net sink for GHGs, our analysis also indicated that cow-calf farms converting from continuous to rotational grazing in SGP region could be either net carbon sinks or low carbon sources for decades. For example, under the intermediate 15-year scenario, cow-calf farms converting from $\mathrm{HC}$ to MP, from $\mathrm{HC}$ to LC and from LC to MP are likely net sinks for GHG with a net $\mathrm{C}$ sequestration rate of $2002.8,1731.6$ and $89.5 \mathrm{~kg} \cdot \mathrm{C} \cdot \mathrm{ha}^{-1} \cdot \mathrm{year}^{-1}$ respectively. Even the most conservative 20-year scenario (Table 4), cow-calf farms converting from $\mathrm{HC}$ to $\mathrm{MP}$ and from $\mathrm{HC}$ to LC are net sinks for $\mathrm{GHG}$ with a net $\mathrm{C}$ sequestration rate of 1414.5 and $1253.3 \mathrm{~kg} \cdot \mathrm{C} \cdot \mathrm{ha}^{-1} \cdot \mathrm{year}^{-1}$. A transition from LC to MP will generate a low net carbon emission rate of $20.5 \mathrm{~kg} \cdot \mathrm{C} \cdot \mathrm{ha}^{-1} \cdot \mathrm{year}^{-1}$ for the 20-year scenario.

Therefore, it is worth noting that even though the GHG emissions in SGP region are higher on a per calf basis compared to the values reported in other regions of the world [16,44], net GHG emissions are likely negative when we take the carbon sequestration into account (Table 4). This is consistent with results from NGP region reported by Liebig et al. [12] where, when using a modest annual SOC sequestration rate of 0.17 tons $\cdot \mathrm{C} \cdot \mathrm{ha}^{-1}$ with the continuously grazed forage base, both heavy and moderately stocked grazing strategies produced substantial carbon sinks of -0.618 and -0.783 tons $\cdot \mathrm{CO}_{2 \mathrm{e}} \cdot \mathrm{ha}^{-1}$.year ${ }^{-1}$ respectively. Overall these systems yielded -0.026 and -0.145 tons $\cdot \mathrm{CO}_{2 \mathrm{e}} \cdot \mathrm{kg}^{-1}$ animal gain while the enteric methane was reported to be 0.484 and 0.176 tons $\cdot \mathrm{CO}_{2 \mathrm{e}} \cdot \mathrm{ha}^{-1} \cdot \mathrm{year}^{-1}$.

If we assume a soil $\mathrm{C}$ sequestration rate of $330 \mathrm{~kg} \cdot \mathrm{C} \cdot \mathrm{ha}^{-1} \cdot \mathrm{year}^{-1}$ as from LC to MP as reported in the 20-year scenario (Table 4), it will take an additional 116 years for the current SOC stock under MP practice to reach that of the native prairie reported by Potter et al. [39], which averaged $160.78 \mathrm{Mg} \cdot \mathrm{C} \cdot \mathrm{ha}^{-1}$ in 
central Texas. Likewise if the sequestration rate of $440 \mathrm{~kg} \cdot \mathrm{C} \cdot \mathrm{ha}^{-1} \cdot \mathrm{year}^{-1}$ from LC to MP as reported in the 15 -year scenario is assumed, then it will take 87 years to reach the SOC level of the native prairie. Thus, the upward trend in $\mathrm{C}$ sequestration will likely continue for a number of decades. When assuming the $\mathrm{C}$ sequestration rate of $1765 \mathrm{~kg} \cdot \mathrm{C} \cdot \mathrm{ha}^{-1} \cdot \mathrm{year}^{-1}$ under 20 -year scenario, which occurred during the transition of HC to MP, it only takes an additional 38 years for the SOC stock under HC grazing to reach the SOC stock value of an average native prairie, or 23 years under the 15 -year scenario. This coincides with the conclusion of Smith [43] and suggests that this high carbon sequestration rate is unlikely to last over the long term.

However, for decades after converting from the continuous grazing to MP grazing practice, the contribution of GHG emission by cow-calf farm in the beef production link is non-significant, non-existent, or negative relative to carbon sequestration rates for ruminants feeding solely on grazed perennial pastures. This is contrary to many commonly reported LCA analyses indicating that cow-calf enterprises account for the highest GHG emission in the beef production [11], which is misleading as most of these analyses do not consider the GHG sequestration in the ecosystem being studied. In addition, these analyses do not consider the GHG emissions generated by cropping practices $[45,49]$ and soil erosion [50] associated with grains fed during the non-grazing portions of the production cycle. Net GHG emissions differ when the $\mathrm{C}$ sequestration under the different grazing practices is considered which underlines the importance of taking into account both GHG emission and C sequestration simultaneously in such analyses.

\section{Conclusions}

Using the LCA approach, this paper calculated GHG emissions of the cow-calf farms in the SGP region. Results show that the overall GHG emissions and main GHG emission sources of the SGP region differ from those of the rest of the U.S. such as the NGP region, and other countries in the world. This indicates the importance of the LCA analysis on a regional basis. In SGP, where according to our findings, overall GHG emissions are higher than the other regions, almost $80 \%$ of GHG emissions are from enteric methane. There is great potential of reducing GHG emission by increasing grass quality and digestibility, which could reduce total GHG emissions by as much as $30 \%$. Compared to continuous grazing, MP grazing can improve grass quality [38] as well as grass production [15], thus, MP grazing strategy is potentially a good option to reduce GHG emission on a cow-calf farm.

Unlike most published work that isolates the analyses of GHG emission and $\mathrm{C}$ sequestration, our paper used field observed SOC data to estimate the $\mathrm{C}$ sequestrations for different grazing management systems. Contrary to the publications claiming that cow-calf farms are the most significant GHG emission source in the beef production link, our results show that cow-calf farms converting from $\mathrm{HC}$ to MP or LC practices in SGP region are likely net carbon sinks. In our study, the highest SOC stock occurred upon converting to MP grazing indicates that among the three different grazing practices we analyzed, MP has the highest carbon sequestration rate. Combined with its potential to significantly lower GHG emissions, we conclude that MP serves as the best carbon mitigation option. 


\section{Acknowledgments}

We thank the Dixon Water Foundation for the financial support of this research under project number $\mathrm{H} 8179$.

\section{Author Contributions}

The study was designed by Tong Wang, W. Richard Teague and Seong Park; Tong Wang carried out the analysis; Richard Teague contributed the field research data; Stan Bevers provided a detailed description of the study system in this paper; Tong Wang and W. Richard Teague lead the preparation of the paper. All authors approved the final manuscript.

\section{Conflicts of Interest}

The authors declare no conflict of interest.

\section{References}

1. Flachowsky G.; Kamphues J. Carbon footprints for food of animal origin: What are the most preferable criteria to measure animal yields? Animal 2012, 2, 108-126.

2. Janzen, H.H. What place for livestock on a re-greening earth? Anim. Feed Sci. Tech. 2010, 166-167, 783-796.

3. Zilverberg, C.J.; Johnson, P.; Weinheimer, J.; Allen, V.G. Energy and carbon costs of selected cow-calf systems. Rangel. Ecol. Manag. 2011, 64, 573-584.

4. McBride, W.D.; Mathews, K., Jr. The diverse structure and organization of U.S. beef cow-calf farms. Avaialble online: http:/www.ers.usda.gov/publications/eib-economic-informationbulletin/eib73.aspx (accessed on 30 September 2015).

5. Delgado, J.A.; Groffman, P.M.; Nearing, M.A.; Goddard, T.; Reicosky, D.; Lal, R.; Kitchen, N.R.; Rice, C.W.; Towery, D.; Salon, P. Conservation practices to mitigate and adapt to climate change. J. Soil Water Conserv. 2011, 66, 118A-129A.

6. Gerrish, J. Management-Intensive Grazing, the Grassroots of Grass Farming; Green Park Press: Ridgeland, MS, USA, 2004.

7. Stinner, D.H.; Stinner, B.R.; Martsolf, E. Biodiversity as an organizing principle in agroecosystem management: Case studies of holistic resource management practitioners in the USA. Agric. Ecosyst. Environ. 1997, 62, 199-213.

8. Teague, R.; Provenza, F.; Kreuter, U.; Steffens, T.; Barnes, M. Multi-paddock grazing on rangelands: Why the perceptual dichotomy between research results and rancher experience? J. Environ. Manag. 2013, 128, 699-717.

9. Teague, W.R.; Kreuter, U.P.; Grant, W.E.; Diaz-Solis, H.; Kothmann, M.M. Economic implications of maintaining rangeland ecosystem health in a semiarid savanna. Ecol. Econ. 2009, 68, 1417-1429.

10. Teague, W.R.; Grant, B.; Wang, H. Assessing optimal configurations of multi-paddock grazing strategies in tallgrass prairie using a simulation model. J. Environ. Manag. 2015, 150, 262-273.

11. Lupo, C.D.; Clay, D.E.; Benning, J.L.; Stone, J.J. Life-cycle assessment of the beef cattle production system for the Northern Great Plains, USA. J. Environ. Qual. 2014, 42, 1386-1394. 
12. Liebig, M.A.; Gross, J.R.; Kronberg, S.L.; Phillips, R.L.; Hanson J.D. Grazing management contributions to net global warming potential: A long-term evaluation in the Northern Great Plains. J. Environ. Qual. 2010, 39, 799-809.

13. Schils, R.L.M.; Olesen J.E.; del Prado, A.; Soussana, J.F. A review of a farm level modeling approach for mitigating greenhouse gas emissions from ruminant livestock systems. Livest. Sci. 2007, 112, 240-251.

14. Soussana, J.F.; Tallec T.; Blanfort, V. Mitigating the greenhouse gas balance of ruminant production systems through carbon sequestration in grasslands. Animal 2010, 4, 334-350.

15. Teague, W.R.; Dowhower, S.L.; Baker, S.A.; Haile, N.; DeLaune, P.B.; Conover, D.M. Grazing management impacts on vegetation, soil biota and soil chemical, physical and hydrological properties in tall grass prairie. Agric. Ecosyst. Environ. 2011, 141, 310-322.

16. Ogino, A.; Orito, H.; Shimada, K.; Hirooka, H. Evaluating environmental impacts of the Japanese beef cow-calf system by the life cycle assessment method. J. Anim. Sci. 2007, 78, 424-432.

17. Bagley, C.P.; Carpenter J.C., Jr.; Feazel J.I.; Hembry F.G.; Huffman D.C.; Koonce K.L. Influence of calving season and stocking rate on beef cow-calf productivity. J. Anim. Sci. 1987, 64, 687-694.

18. Arthington, J.D.; Bohlen, P.; Roka F.M. Effect of Stocking Rate on Measures of Cow-Calf Productivity and Nutrient Load in Surface Water Runoff; University of Florida, IFAS Extension: Gainesville, FL, USA, 2003.

19. Arthington, J.D.; Roka, F.M.; Mullahey, J.J.; Coleman, S.W.; Muchovej, R.M.; Lollis, L.O.; Hitchcock, D. Integrating ranch forage production, cattle performance, and economics in ranch management systems for southern Florida. Rangel. Ecol. Manag. 2007, 60, 12-18.

20. Scaglia, G.; Swecker. W.S., Jr; Fontenot, J.P.; Fiske, D.; Fike, J.H.; Abaye, A.O.; Peterson, P.R.; Clapham, W.; Hall, J.B. Forage systems for cow-calf production in the Appalachian region. J. Anim. Sci. 2008, 86, 2032-2042.

21. Hoveland, C.S.; McCann, M.A.; Hill, N.S. Rotational vs continuous stocking of beef cows and calves on mixed endophyte free tall fescue-bermudagrass pasture. J. Prod. Agric. 1997, 10, 245-250.

22. McCann, M.A. Rotational vs. continuous grazing. In Proceedings of the Southeastern Sustainable Animal Waste Workshop; University Georgia: Tifton, GA, USA, 1997; pp. 277-280.

23. Chestnut, A.B.; Fribourg, H.A.; Onks, D.O.; McLaren, J.B.; Gwinn, K.D.; Mueller, M.A. Performance of cows and calves with continuous or rotational stocking of endophyte-infested tall fescue-clover pastures. J. Prod. Agric. 1992, 5, 405-408.

24. Wyatt, W.E.; Venuto, B.C.; Gillespie, J.M.; Blouin, D.C.; Redfearn, D.D. Effects of year-round stocking rates and stocking methods on performance of cow-calf pairs grazing dallisgrass-common bermudagrass pastures overseeded with annual ryegrass. Prof. Anim. Sci. 2012, 28, 417-432.

25. Intergovernmental Panel on Climate Change (IPCC). Guidelines for National Greenhouse Gas Inventories; Eggleston H.S., Buendia L., Miwa, K., Ngata, T., Tanabe, K., Eds.; National Greenhouse Gas Inventories Programme: Hayama, Japan, 2006.

26. Intergovernmental Panel on Climate Change (IPCC). Climate Change 2007: The Scientific Basis; Cambridge University Press: Cambridge, UK, 2007. 
27. Environmental Protection Agency (EPA). Unit Conversions, Emissions Factors, and Other Reference Data. 2004. Available online: http://www.epa.gov/cpd/pdf/brochure.pdf (accessed on 14 July 2015).

28. Westberg, H.; Lamb, B.; Johnson, K.A.; Huyler, M. Inventory of methane emissions from U.S. cattle. J. Geophys. Res. 2001, 106, 633-642.

29. EPA. Inventory of U.S. Greenhouse Gas Emissions and Sinks: 1990-2010 EPA 430-R-12-001: Annex 3 Methodological Descriptions for Additional Source or Sink Categories; U.S. Environmental Protection Agency: Washington, DC, USA, 2012.

30. ICF Consulting. Methods for Estimating Greenhouse Gas Emissions from Manure Management. In Proceedings of the Greenhouse Gas Committee, Emission Inventory Improvement Program, U.S. EPA, Washington, DC, USA, September 1999.

31. ICF Consulting. Methods for Estimating Greenhouse Gas Emissions from Agricultural Soils. In Proceedings of the Greenhouse Gas Committee, Emission Inventory Improvement Program, U.S. EPA, Washington, DC, USA, September 1999.

32. Van Zeist, W.J.; Marinussen, M.; Broekema, R.; Groen, E.; Kool, A.; Dolman, M.; Blonk, H. LCI Data for the Calculation Tool Feedprint for Greenhouse Gas Emissions of Feed Production and Utilization -Crushing Industry; Blonk Consultants: Gouda, The Netherlands, 2012.

33. Wang, T.; Park S.C.; Bevers S.; Teague, R.; Cho, J. Factors affecting cow-calf herd performance and greenhouse gas emissions. J. Agric. Resour. Econ. 2013, 38, 435-456.

34. S\&T Consultants Inc. National Cottonseed Products Association Petition for Renewable Fuel Pathway for Biodiesel Using Cottonseed Oil. Appendix A. Cottonseed Oil LCA Data. 2011. Available online: http://www.cottonseed.com/Whatsnew/Cottonseed\%20-\%20RFS2\%20\%20Petition\%20Appendices.pdf (accessed on 14 July 2015).

35. National Cattlemen's Beef Association. 2014 National Cattlemen Statistics. Available online: http://www.beefusa.org/beefindustrystatistics.aspx (accessed on 23 September 2015).

36. Ryan, B.; Tiffany, D.G. Minnesota agricultural Energy Use and the Incidence of a Carbon Tax; Institute for Local Self Reliance: Minneapolis, MN, USA, 1998.

37. Del Grosso J.; Walsh, M.; Duffield, J. US Agriculture and Forestry Greenhouse Gas Inventory: 1990-2005; USDA Technical Bulletin: Washington, DC, USA, 2008.

38. Heitschmidt, R.K.; Dowhower, S.L.; Walker, J.W. Some effects of a rotational grazing treatment on quantity and quality of available forage and amount of ground litter. J. Range Manag. 1987, 40, 318-321.

39. Potter, K.N.; Torbert, H.A.; Johnson, H.B.; Tischler, C.R. Carbon storage after long-term grass establishment on degraded soils. Soil Sci. 1999, 164, 718-725.

40. USDA Natural Resources Conservation Service (NRCS). Soil Quality Indicators. 2009. Available online: http://go.usa.gov/zUAH_(accessed on 14 July 2015).

41. Stephenson, K.; Bosch, D.; Groover, G. Carbon credit potential from intensive rotational grazing under carbon credit certification protocols. In Proceedings of the American Agricultural Economics Association Annual Meeting, Denver, CO, USA, 1-4 August 2004.

42. Gascoigne, W.R.; Hoag, D.; Koontz, L.; Tangen, B.A.; Shaffer, T.L.; Gleason, R.A. Valuing ecosystem and economic services across land-use scenarios in the Prairie Pothole Region of the Dakotas, USA. Ecol. Econ. 2011, 70, 1715-1725. 
43. Smith, P. Do grasslands act as a perpetual sink for carbon? GCB 2014, 20, 2708-2711.

44. Pelletier, N.; Pirog, R.; Rasmussen, R. Comparative life cycle environmental impacts of three beef production strategies in the upper Midwestern United States. Agric. Syst. 2010, 103, 380-389.

45. DeRamus, H.A.; Clement, T.C.; Giampola, D.D.; Peter C.D. Methane emissions on beef cattle on forages: Efficiency of grazing management systems. J. Environ. Qual. 2003, 32, 269-277.

46. Follett, R.F.; Reed, D.A. Soil carbon sequestration in grazing lands: Societal benefits and policy implications. Rangel. Ecol. Manag. 2010, 63, 4-15.

47. Soussana, J.F.; Loiseau, P.; Vuichard, N.; Ceschia, E.; Balesdent, J.; Chevallier, J.T.; Arrouays, D. Carbon cycling and sequestration opportunities in temperate grasslands. Soil Use Manag. 2004, 20, 219-230.

48. Soussana, J.F.; Allard, V.; Pilegaard, K. Full accounting of the greenhouse gas $\left(\mathrm{CO}_{2}, \mathrm{~N}_{2} \mathrm{O}, \mathrm{CH}_{4}\right)$ budget of nine European grassland sites. Agric. Ecosyst. Environ. 2007, 121, 121-134.

49. Vermeulen, S.J.; Campbell. B.M.; Ingram, J.S.I. Climate Change and Food Systems. Annu. Rev. Environ. Resour. 2012, 37, 195-222.

50. Lal, R. Soil erosion and the global carbon budget. Environ. Int. 2003, 29, 437-450.

(C) 2015 by the authors; licensee MDPI, Basel, Switzerland. This article is an open access article distributed under the terms and conditions of the Creative Commons Attribution license (http://creativecommons.org/licenses/by/4.0/). 